\title{
The airway fluid analysis: methods and interpretation for the athletic horse*
}

\author{
Avaliação do fluido das vias aéreas posteriores: \\ metodologia e interpretação para cavalos atletas
}

\author{
Pedro Vicente Michelotto Jr., ${ }^{* *}$ Daniel Augusto Barroso Lessa, ${ }^{* * *}$ Katia Moreira da Silva, ${ }^{* * *}$ Karla Ribeiro S. Gawlowski, ${ }^{* *}$ \\ Wilson Roberto Fernandes ${ }^{* * * *}$
}

\begin{abstract}
Respiratory inflammatory diseases are considered one of the main causes of poor performance and health impairment in athletic horses. Inflammatory airway disease (IAD), recurrent airway obstruction (RAO) and exercise induced pulmonary hemorrhage (EIPH) are the main diagnosed disorders, and respiratory secretion analysis is considered one of the most sensitive diagnostic methods for these diseases. Tracheal aspirate and bronchoalveolar lavage are considered important diagnostic tools and have been largely utilized in research as well as in clinical settings. Currently, many studies have been done to improve these techniques, allowing a significant progress in result analysis and interpretation. The present article aims to review the diagnostic methods in attaining respiratory tract secretions, collection techniques, preparation and interpretation of cytological samples, as well as enzymatic analysis of these fluids are described with the purpose to gain efficiency in the diagnosis of equine respiratory diseases.
\end{abstract}

Keywords: horse, tracheal wash, bronchoalveolar, cytology.

\section{Resumo}

As doenças respiratórias inflamatórias são consideradas entre as principais causas de queda de rendimento desportivo e perda em qualidade de vida em cavalos desportistas. Dentre elas, a doença inflamatória das vias aéreas (DIVA), a obstrução recorrente das vias aéreas (ORVA), e a hemorragia pulmonar induzida pelo exercício (HPIE), são as principais afecções, e a análise das secreções respiratórias é considerado o método mais sensível para o diagnóstico destas doenças. O lavado traqueal e o lavado broncoalveolar são as técnicas empregadas para a obtenção das amostras e diagnóstico, utilizados em pesquisa e na prática clínica. Atualmente, muitos são os estudos procurando aprimorar estas técnicas diagnósticas, melhorando a análise e interpretação dos resultados obtidos. O presente artigo visou revisar os métodos diagnósticos para a obtenção de secreções do trato respiratório, técnica de colheita, preparação e interpretação das amostras citológicas, bem como a análise enzimática destes fluidos são descritos com o objetivo de se ganhar eficiência no diagnóstico das doenças respiratórias dos cavalos.

Palavras-chave: cavalo, lavado traqueal, broncoalveolar, citologia.

\section{Introduction}

There were important advances in the understanding of equine lung diseases as well as considerable progress in ancillary diagnostic procedures during the last two decades. It is known that such techniques may not be used to replace a complete physical examination. However, facing situations such as the decline in athletic performance without specific clinical signs of respiratory tract disease, auxiliary diagnostic techniques are able to detect sudden alteration of the lungs (Couëtil et al., 2001; Hodgson and Hodgson, 2007).

The equine practitioner can collect samples from the respiratory tract, even under field conditions. Tracheal aspirate (TA), tracheal wash (TW), and bronchoalveolar lavage (BAL) are the most common sampling techniques (McKane et al., 1993; Hoffman, 1999; Hewson and Viel, 2002; Hodgson and Hodgson, 2003; Hughes et al., 2003; Mazan and Hoffman, 2003; Robinson et al., 2006; Christley and Rush, 2007; Hegedüs et al., 2007; Hodgson and Hodgson 2007; Lessa et al., 2007). The cytological diagnosis will be influenced by the chosen technique.

The tracheal aspirate (TA) is a practical and well tolerated sampling technique that can be performed during an endoscopic examination of the airways. A polyethylene tube is introduced through the endoscopic biopsy channel to aspirate the secretion from the distal end of the trachea, adjacent to the carina. A quantity of $30 \mathrm{~mL}$ of sterile $0.9 \%$ sodium chloride solution can also be instilled to perform a tracheal wash (TW) (Mansmann and Knight, 1972). In this cases, an adequate sample should contain

\footnotetext{
* Recebido em 24 de agosto de 2012 e aceito em 14 de fevereiro de 2013.

** School of Agricultural Sciences and Veterinary Medicine, Pontifícia Universidade Católica do Paraná (PUCPR), BR 376, Km 14, Costeira, CX Postal 129, São José dos Pinhais, Paraná, CEP 83010-500, Brazil.

*** Department of Veterinary Medicine and Pathology, Veterinary College, Universidade Federal Fluminense (UFF), Brazil.

**** Department of Veterinary Medicine, Universidade de São Paulo (USP), Brazil.

Corresponding author: P.V. Michelotto Jr. Address: Rua Luiz Alberti, 169, Campo Comprido, Curitiba, Paraná, CEP 81220-050, Brazil. Telephone: 5541 9973-6807. Fax: 5541 3299-4327. Email: michelottojunior@yahoo.com.br.
} 
cells from all the levels of the pulmonary tree, including columnar epithelial cells (trachea and bronchi), cuboid cells (distal bronchi and bronchioles), and alveolar macrophages. On the other hand, samples become unviable for bacterial culture (Hodgson and Hodgson, 2007). Moreover, horses recently transported must rest for a minimum of 12 hours before airway sampling is proceeded (Hodgson and Hodgson, 2003).

The concentration of cells in TA can be modified by exercise. Indeed, there was a higher percentage of neutrophils in the TA of racehorses after the competition than before (Malikides et al., 2007). Therefore, the airway sampling is recommended within thirty to sixty minutes after the exercise to guarantee a higher diagnostic value, as it should contain more secretion and increasing the chance of lung disease diagnosis (Hodgson and Hodgson, 2007).

Conversely, the bronchoalveolar lavage (BAL) is the preferred technique of sampling for the diagnosis of lungs inflammatory conditions (Couëtil et al., 2007). The BAL can also be performed using the endoscope or through the blind introduction of an equine BAL catheter until lodged in a bronchus. Similar than TA, $B A L$ can be achieved under field conditions, using the adequate protocol of horse sedation (Fernandes et al., 2000; Hewson and Viel, 2002; Mazan and Hoffman, 2003; Viel and Hewson, 2003; Lessa et al., 2005; Hodgson and Hodgson, 2007; Michelotto Jr et al., 2010).

It is important to consider the cytological evaluation of the airways as a part of the clinical routine in equine practice, because respiratory disorders play a significant role in health and performance in horses of different ages and sport activities (Viel and Hewson, 2001). Moreover, although inflammatory airway disease (IAD) and exercise-induced pulmonary hemorrhage (EIPH) can be clinically undetected, they can impair athletic performance (Couëtil, 2003; Sánchez et al., 2005). Diagnosis, severity, and prognosis as well as the prevalence of IAD and $\mathrm{EIPH}$, depend on cytological evaluation to avoid erroneous or incomplete diagnosis (McKane et al., 1993; Doucet and Viel, 2002; Couëtil et al., 2007).

There are variations in cellular profiles between the TA and BAL samples. The cellular profile of one technique can be different than the other for a same horse (Derksen et al., 1989; Hewson and Viel, 2002; Hodgson and Hodgson, 2003), and a coincident diagnosis was mentioned to occur in approximately $60 \%$ of the cases (Christley and Rush, 2007).

Moreover, TA should be chosen when bacterial pneumonia or pleuropneumonia are suspected and horses with poor performance or persistent cough should be evaluated through both techniques to obtain a complete information of the airways condition (Derksen et al., 1989; Viel et al., 2000; Hodgson and Hodgson, 2007).

\section{Handling and Preparation of Samples}

Preferentially, smears should be performed as soon as a TA or $\mathrm{BAL}$ is proceeded. Considering the BAL, the instilled fluid volume varies considerably, and it was established at the Michigan Workshop that a standard volume for BAL of 250 to $500 \mathrm{~mL}$ should be used (Hewson and Viel, 2002; Hodgson and Hodgson, 2007).

Once the smears are prepared, the most common staining techniques are the Wright-Giemsa, Diff-Quick, May-Grünwald, Leishmann (Hoffman, 1999; Hewson and Viel, 2002; Viel and Hewson, 2003) and Rosenfeld stains (Fernandes et al., 2000; Lessa et al., 2007). Identification of mast cells can be improved using Leishmann and Toluidine blue stains (Hoffman, 1999; Hughes et al., 2003; Hodgson and Hodgson, 2007). The detection of hemosiderophages in horses with EIPH can be easily performed using Diff-Quick and Wright-Giemsa (Mazan and Hoffman, 2003), but Prussian blue stain is recommended to visualize the hemossiderin (Doucet and Viel, 2002).

\section{Interpretation of the Cytological Findings Due to Exercise}

Total nucleated cells count (TNCC) from BAL fluid does not change after a strenuous exercise, although it increased after a period of training in racehorses (Raidal et al., 2000).

The ciliated epithelial cells are commonly found in TA samples and could be present in high number in samples collected during endoscopy. These cells are absent or occasionally identified in BAL fluid. However, an increase in epithelial cells in the sample can be observed as a consequence of viral infection (Viel and Hewson, 2003; Lessa et al., 2007) or after exercising breathing cold air (Davis et al., 2005).

The alveolar macrophages are the predominant cells, $60-70 \%$ of the total, in TA and BAL samples of healthy horses. These cells can contain a variety of phagocytized structures as erythrocytes, apoptotic cells, fungi spores, pollen and hemossiderin (Hoffman, 1999; Hoffman et al., 2003; Viel and Hewson, 2003; Michelotto $\mathrm{Jr}$ et al., 2010). An increased number of macrophages were detected in thoroughbreds with chronic cough (McKane et al., 1993).

Multinucleated macrophages, also known as multinucleated giant macrophages or giant cells, are the product of two or more fused macrophages that constitute an important finding on inflammatory processes in the lung (Anderson et al., 1999), and might represent a Th2 immune response (Helming and Gordon, 2007). These cells can be observed in small quantities in TA and BAL from horses without inflammatory signs of the airways, but an increase is observed in cases of chronic inflammation (Hodgson and Hodgson, 2007).

The lymphocytes appear in small number in TA, representing $<10 \%$ of the total cells (Hoffman et al., 2003; Hodgson and Hodgson, 2007). However, lymphocytes are found in higher proportions in BAL, representing $30-35 \%$ of the total cells (Hoffman et al., 2003; Viel and Hewson, 2003). Interpretation of the increase in the percentage of lymphocytes is difficult, due to the high variation in BAL fluid of normal horses. Nevertheless, increased percentage of lymphocytes was reported in racehorses with exercise intolerance or chronic cough, although its significance remain unknown (Hodgson and Hodgson, 2007).

Neutrophils are found in small quantities in the airways of healthy horses, but as long as these cells are highly responsive, its percentage can vary quickly. Migration of neutrophils to the respiratory tract can be observed as soon as 5 hours after a stimulus (Brazil, 2001; Léguillette, 2003). Neutrophils are found in higher proportion in TA than in $\mathrm{BAL}$, possibly reflecting the highest exposition of the proximal airways to noxious factors. It is considered a percentage of neutrophils of $<20 \%$ in TA (Hoffman et al., 2003; Hodgson and Hodgson, 2007) and of < $5 \%$ in BAL for normal horses (Hoffman et al., 2003; Viel and Hewson, 2003). 
Increased percentage of inflammatory cells is a characteristic of inflammatory airway disease (IAD) in racehorses. The increased number of neutrophils in BAL was correlated with reduced athletic performance (Couëtil et al., 2007), nevertheless in the study by Holcombe et al. (2006) higher neutrophil counts was detected in racehorses that had already competed in comparison with stable mates that did not. Although it was demonstrated that there are different neutrophil counts for healthy $(3.3 \pm 1.5)$ and asymptomatic IAD horses $(7.1 \pm 3.8)$ (Sad, 2007), increased neutrophil counts in the tracheal wash (TW) of horses with cough was associated with an increased risk of bacterial infection (Christley et al., 2001).

Eosinophils are found in a very low number $(0 \%-1 \%)$ in TA and BAL of clinically normal adult horses (Hodgson and Hodgson, 2007). An increased percentage of eosinophils in BAL may be a transitory event, even when additional collection is performed over 24 hours after the first sampling (Viel and Hewson, 2003). On the other hand, airways hyperresponsiveness was associated with an increased number of eosinophils in BAL in young racehorses (Hare and Viel, 1998).

Mast cells are found in small quantities in the airways, but they are more prevalent in BAL than in TA. An increased percentage of mast cells in BAL was correlated with airways hyperresponsiveness in horses with chronic cough, impairment in pulmonary function and reduced athletic performance (Hoffman et al., 1998).

Curschmann's spirals constitute a mucus matrix obstructing the small airways, observed in cases of increased mucus production in small bronchioles (Zinkl, 2002), specially in chronic pulmonary inflammation (Deconto, 1985; Viel and Hewson, 2003).

In cases of IAD a single inflammatory cell type can predominate in BAL i.e. mast cells, eosinophils, lymphocytes, or neutrophils, but a mixed inflammatory response can also be observed. Predominance of a single cell type seemingly occurs in early stages of pulmonary inflammation as well as a mixed response occurs while inflammatory response advances (Viel and Hewson, 2003).

Exercise practice and its effects on organism have been widely studied, could be considered either beneficial or deleterious for health, depending on intensity, duration, and exercise conditions. It is well known that physical exercise, as stress inducer, causes modifications of immune system functions (Leandro et al., 2002). Likewise, effects of exercise on airways have been studied in a variety of species.

Mice subdued to moderate aerobic training showed a decrease in pulmonary leukocyte infiltrate. This result suggested a beneficial effect of exercise in human patients with asthma (Pastva et al., 2004).

On human asthma, a condition compared to pulmonary inflammation in horses (IAD or RAO), the exercise-induced bronchoconstriction caused epithelial injury, leading to an increase in the percentage of epithelial cells (Hallstrand et al., 2005) and eosinophils in respiratory secretion that was associated to augment of cysteinyl leukotrienes and prostaglandin E2 (Kivity et al., 2000; Hallstrand et al., 2005). Increased concentration of epithelial cells was also evident in BAL in horses training in cold air $\left(-5^{\circ} \mathrm{C}\right)$. It was associated with increased Th2 cytokines (Davis et al., 2005).
The increased number of eosinophils was also observed in secretions from runners with bronchial hyperresponsiveness, which also showed increased nitric oxide in exhaled air and exacerbation of exercise-induced symptoms (Vergès et al., 2005).

It was also demonstrated in runners that prolonged physical exercise caused significant stress on the respiratory system (Denguezli-Bouzgarrou et al., 2006). A season of training for long distance races induced increase of macrophages and neutrophils in airways, resulting in exercise-induced pulmonary inflammation. Basal percentage of neutrophils on phlegm kept high, suggesting a chronic increment of neutrophils in airways, but of insufficient magnitude to clinically manifest. Authors corroborated increase of histamine, interleucin-8 (IL-8), leukotrienes $\mathrm{B}_{4}\left(\mathrm{LTB}_{4}\right)$, and leukotrienes $\mathrm{E}_{4}\left(\mathrm{LTE}_{4}\right)$ as well as cytological changes (DenguezliBouzgarrou et al., 2007).

Training also caused increment on the percentage of neutrophils in BAL in thoroughbred yearlings in advanced training stage but that had not competed yet. Besides an increase on neutrophils population, an elevation of TNCC and protein concentration in BAL was found, representing airway inflammation in race yearlings. In spite of IAD has not yet been clearly defined (Couëtil et al., 2007), this study identified the role of platelet aggregation factor (PAF) on pulmonary inflammation in thoroughbred yearlings during the initial stage of their athletic life (Michelotto Jr et al., 2008b).

There were obtained $10.5 \%$ neutrophils, $2.8 \%$ hemosiderophages in BAL collected from yearlings not yet in competition, 24 hours after intense exercise. Thus, it was observed pulmonary inflammation and evidences of EIPH, in early stages of athletic life of race yearlings (Michelotto Jr et al., 2008a).

Endoscopic and TA cytology evaluation of 27 healthy American Quarter horses after barrel racing showed neutrophils percentage of $23.1 \%$, with three horses presenting an increase in the number of eosinophils. Thus, it was confirmed that pulmonary inflammation can be identified by cytology, even before clinical signs appear, as long as the evaluated horses did not show clinical history of respiratory disease. The endoscopic evaluation evidenced EIPH on six horses, although only three showed hemosiderophages in TA, demonstrating that it can be a gap time between presence of blood on trachea and hemosiderophages in airways (Michelotto Jr et al., 2007a).

\section{Determination of the enzimatic activity in airway fluids for the diagnosis of inflammatory airway diseases}

The use of enzyme activities for the diagnosis of respiratory diseases has been demonstrated in different species (HennigPauka et al., 2001; Maden et al., 2001; Art et al., 2006) and can be used for horses.

The activity of alkaline phosphatase (AP) can be emphasized. The AP activity was associated with the synthesis of phospholipids and protein components of the surfactant, as an increased activity of the pneumocyte type II in rat lungs (Kalina et al., 1990). In humans, the increased activity of AP in BAL fluid is related to interstitial and fibrotic lung diseases as well as acute pneumopathy, with or without infection, that result in significant epithelial lesion (Sanchez et al. 2000, Capelli et al. 1997). 
Jorge (2011) demonstrated the reduction of AP activity in BAL fluid of police horses with IAD cytological profile, in comparison with normal horses $(2,041.9 \pm 761.1 \mathrm{UI}$ vs. $3,245.4 \pm 1,449.9 \mathrm{UI})$. This was inferred to the persistent pulmonary inflammation of IAD horses, although not an intense inflammatory process, could have influenced the number and function of pneumocytes type II cells, resulting in reduced AP activity. Conversely, Viscardi (2012) observed an increased AP activity $(18,865.05 \pm 11,233.40$ UI vs. $10,282.85 \pm 5,856.97 \mathrm{UI})(p=0,021)$ in tracheal wash of horses of the same population. This difference in AP activity was attributed to sampling method. Neutrophils are present in increased number in tracheal wash of healthy and IAD horses, and an important production of AP was already demonstrated for this cell type (Malikides et al. 2003).

\section{Exercise-induced Pulmonary Hemorrhage (EIPH)}

The EIPH was initially described on racehorses by Pascoe et al. in 1981, based upon the endoscopic observation of blood in airways after exercise. Thenceforth, it has been described an EIPH prevalence of $50 \%$ in horses of different sport modalities (Doucet and Viel, 2002).

A study of 121 thoroughbreds evaluated 60 minutes after racing by endoscopy and TA cytology, showed an incidence of EIPH of $76.9 \%$, even without epistaxis. It was also found that race track conditions influenced on incidence of EIPH that was $82.2 \%, 67 \%$ and $60 \%$ on dry, moist and wet sand respectively. It was thought that the highest incidence in horses running on dry sand was because the higher speed reached on this kind of ground. Cytology of TA detected hemosiderophages in $64.4 \%$ of the horses evaluated. No relation was found between hemosiderophages in TA and place race position. However, regarding the presence of blood, $65.5 \%$ of horses considered as losers, showed some quantity of blood in the trachea, while this value was $34.4 \%$ for winners (Eppinger, 1990).

Considered as an important finding on EIPH diagnosis, hemosiderophages were demonstrated in tracheal secretions and BAL of animal suffering the disease, but they were also observed in horses without history or clinical signs of EIPH (Doucet and Viel, 2002).

In another study, the use of BAL cytology to evaluate 62 race thoroughbreds under training evidenced free erythrocytes in $73 \%$ and hemosiderophages in $90 \%$ of the horses examined. Thus, the authors concluded that BAL cytology was able to identify a higher prevalence of EIPH as compared with endoscopy alone (McKane et al., 1993).

The quantity of erythrocytes in BAL (Meyer et al., 1998; Geor et al., 2001; Kindig et al., 2001; Epp et al., 2006), as well as

\section{Competing Interest}

The authors declare no competing interests.

\section{References}

ART, T.; FRANCK, T.; LEKEUX, P.; DE MOFFARTS, B.; COUËTIL, L.; BECKER, M.; KOHNEN, S.; DEBY-DUPONT, G.; SERTEYN, D. Myeloperoxidase concentration in bronchoalveolar lavage fluid from healthy horses and those with recurrent airway obstruction. The Canadian Journal of Veterinary Research, v. 70, p. 291-296, 2006 hemosiderophages, can also be used to identify and evaluate $\mathrm{EIPH}$. It was demonstrated that, as compared with control animals, IEPH horses showed increased erythrocyte numbers after exercise, and became normal after one week. Related to hemosiderophages, it was confirmed their augment in BAL one week after exercise, remaining high for three weeks (Meyer et al., 1998). Thus, hemosiderophages in BAL can be considered as the most sensible way to evaluate IEPH severity (Sánchez et al., 2005).

The total hemossiderin score (THS) has been used to determine hemoptysis severity in humans (GOLDE et al, 1975) and horses (DOUCET e VIEL, 2002). THS was previously demonstrated for the diagnosis of EIPH in the BAL of healthy polo horses. In this study, $27.6 \%$ of the horses that presented blood in endoscopy had an increased TSH, as only $11.5 \%$ of horses without tracheal blood had increased TSH (Silva 2010).

The effects of IEPH on athletic performance, as well as the methods to identify important changes related to airway hemorrhage in horses have been described. The pulmonary modifications identified are hyperplasia and hypertrophy of alveolar epithelial cells, and interstitial fibrosis. Nevertheless, these changes were not observed after blood instillation in airways (Derksen et al., 2007).

Thus, prognosis on a horse showing IEPH can be achieved through identification of inflammatory cells in BAL (Doucet e Viel, 2002). The presence of both inflammatory cells and hemosiderophages offers a poor prognosis (Viel e Hewson, 2003).

The increased number of eosinophils in the BAL fluid of horses suffering EIPH was previously demonstrated (Viel and Hewson, 2003) and TW (Hegedüs et al., 2007). The increase of neutrophil number was also evident in racehorses with IEPH as compared with controls (Hegedüs et al., 2007), but the observation of fine mucus cords, foamy macrophages, and high cellularity levels, with neutrophils and lymphocytes predominating, also constitutes a cytological finding in horses with IEPH and IAD.

\section{Conclusion}

Many studies demonstrated the importance of the evaluation of athlete horses through airway cytology, especially regarding chronic cough diagnosis and drop in sportive performance. Diagnosis on IEPH can be accurately achieved using cytological techniques. Nevertheless, IAD can show different cytological profiles, which can be attributed to lack of information on its physiopathology. Anyhow, airway samples can be obtained, without difficulties by TA, TW and BAL techniques, resulting in complete understanding of airway status in horses.
CAPELLI, A.; LUSUARDI, M.; CERUTTI, C.G.; DONNER, C.F. Lung alkaline phosphatase as a marker of fibrosis in chronic interstitial disorders. American Journal Respiratory Critical Care Medicine, v. 155, n. 1, p. 249-253, 1997

DOUCET, M.Y. \& VIEL, L. Clinical, radiographic, endoscopic, bronchoalveolar lavage and lung biopsy findings in horses with exercise-induced pulmonary hemorrhage. Canadian Veterinary Journal. v. 43, p. 195-202, 2002. 
GOLDE, D.W. DREW, W.L. KLEIN,H. Z. Occult pulmonary hemorrhage in leukemia. British Medical Journal v. 2, p. 166-168, 1975.

HENNIG-PAUKA, I.; GANTER, M.; GERLACH, G. F.; ROTHKÖTTER, H. J. Enzyme activities, protein content and cellular variables in the pulmonary epithelial lining fluid in selected healthy pigs. Journal of Veterinary Medicine, v. 48, p. 631-639, 2001.

HOFFMAN, A.M. Bronchoalveolar lavage technique and cytological diagnosis of small airway inflammatory disease. Equine Veterinary Education, v.11, n. 6, p. 330-336, 1999.

JORGE, M.L.L. Atividade da Fosfatase alcalina (EC 3.1.3.1) no fluido epitelial pulmonar de equinos da polícia militar do Estado do Rio de Janeiro. 2011, 52 f. Dissertação (Mestrado) - Faculdade de Veterinária - Universidade Federal Fluminense, Niterói, 2011.

KALINA, M; LEVI, D.; RIKLIS, S. Modulation of alkaline phosphatase activity in alveolar type II like cells. Histochemistry, v. 95, p. 97-103, 1990.

MADEN, M.; ALTUNOK, V.; BIRDANE, F.M.; ASLAN, V.; NIZAMILIOGLU, M. Specific enzyme activities in bronchoalveolar lavage fluid as an aid to diagnosis of tracheobronchitis and bronchopneumonia in dogs. Research in Veterinary Science, v. 71, n. 2, p. 141-145, 2001.

MALIKIDES, N.; HUGHES, K.J.; HODGSON, D.R. et al. Comparison of tracheal aspirates and bronchoalveolar lavage in racehorses. 2. Evaluation of the diagnostic significance of neutrophil percentage. Australian. Veterinary. Journal, v. 81, p. 685-687, 2003.
SAD, E.P Citologia broncoalveolar de equinos sadios e doentes assintomáticos com doença inflamatória das vias aéreas (DIVA) pertencentes ao Regimento Escola de Cavalaria Andrade Neves/ EB/RJ. 2007. 65 f. Dissertação (Mestrado) - Faculdade de Veterinária - Universidade Federal Fluminense, Niterói, 2007

SANCHEZ, N.M.R.; FERNANDEZ-CONDE, M.E.; OLIVER A. C.; HURTADO S. J. A; SAMANIEGO M. M. Alkaline phosphatase isoenzymes in serum and bronchoalveolar lavage from patients with bronchopulmonary disease. Anales de Medicina Interna, v. 17, n. 4, p. 182-185, 2000.

SILVA, K.M. Achados citológicos em lavados traqueobrônquicos de equinos de polo após o exercício. 2010. 57 f. Dissertação (Mestrado) -Faculdade de Veterinária - Universidade Federal Fluminense, Niterói, 2010.

VIEL, L.; HEWSON, J. Bronchoalveolar lavage. In: ROBINSON, N.E. (Ed.). Current therapy in equine medicine. 5. ed. Philadelphia: Saunders, 2003, p. 407-411.

VISCARDI, V. Determinação da atividade da fosfatase alcalina (EC 3.1.3.1.) no lavado traqueal de equinos da Polícia Militar do Estado do Rio de Janeiro. 2012. 50 f. Dissertação (Mestrado) - Faculdade de Veterinária - Universidade Federal Fluminense, Niterói, 2012. 